\title{
Influence of cultivar and UGmax on antioxidative properties of carrot roots (Daucus carota L.) and their stability during freezing process
}

\section{Wpływ odmiany i preparatu UGmax na właściwości antyoksydacyjne korzeni spichrzowych marchwi (Daucus carota L.) i ich stabilność w procesie mrożenia}

\begin{abstract}
* Dr hab. inż. Anna J. Keutgen, prof. nadzw., Faculty of Agriculture and Biotechnology Department of Food Technology, University of Technology and Life Sciences in Bydgoszcz, Kordeckiego 20A St., 85-225 Bydgoszcz, Poland; Department of Crop Sciences, Division of Vegetables and Ornamentals, University of Natural Resources and Life Sciences, Gregor Mendel Str. 33, 1180 Vienna, Austria, akeutgen@utp.edu.pl
\end{abstract}

** Dr inż. Elżbieta Wszelaczyńska, dr inż. Jarosław Pobereżny, Faculty of Agriculture and Biotechnology, Department of Food Technology, University of Technology and Life Sciences in Bydgoszcz, Kordeckiego 20A St., 85225 Bydgoszcz, Poland,

Keywords: measurement uncertainty, sample heterogeneity, experimental method, method validation, method accuracy, method precision, certified material

Słowa kluczowe: niepewność pomiaru, niejednorodność próbki, metoda doświadczalna, walidacja metody, dokładność metody, precyzja metody, certyfikowane materiały

\section{Abstract}

In the present experiment, the significance of cultivar (conventional and coloured) and of the application of the soil fertility enhancer UGmax on health-promoting properties of carrot roots subjected to the freezing process of carrot cubes after water blanching was investigated. The selection of cultivar turned out to be highly significant with respect to the development of health-promoting properties of carrot roots. The highest antioxidant properties were found in the purple cultivar 'Deep Purple'. Its mean antioxidant capacity accounted for $5.31 \mathrm{mmol} \mathrm{Fe}{ }^{+2} \cdot \mathrm{kg}^{-1}$ f.m. Essential for health-promoting properties were the contents of anthocyanins $\left(R^{2}=0.83\right)$ chlorogenic acid $\left(R^{2}=0.81\right)$ and total polyphenolics $\left(R^{2}=0.71\right)$. The application of the biological agent UGmax improved the quality of carrot significantly, increasing the content of total carotenoids and reducing the losses of ascorbic acid during processing. The freezing process negatively influenced the antioxidative properties of carrot irrespective of cultivar and applied agro-technique (use of UGmax), especially in the case of water-soluble antioxidants such as anthocyanins and ascorbic acid.

() IOŚ-PIB

\section{INTRODUCTION}

Carrot is one of the most popular vegetables in Poland, which is the biggest producer of it in Europe. In Poland, $60 \%$ of yield is used for industrial purposes such as the production of juice and frozen or dried products. The most important is the production of frozen carrots [Nosecka 2008]. The popularity of carrot products is combined with its high sensory properties, high nutritional and health-promoting values, especially of the frozen products. They are rich in carotenoids, polyphenolics, minerals and sugars [Platta, Kolenda, 2008; Fik et al. 2008]. However, although the freezing process belongs to the best preservation methods, during this processing negative changes such as enzymatic browning, loss of cell sap and nutritional substances, colour and consistence changes or microbiological contamination may occur [Lavelli et al. 2006]. Freezing as such preserves the present state of quality. For the quality of the final

\section{Streszczenie}

W przedstawionych badaniach zweryfikowano znaczenie odmiany (konwencjonalne i kolorowe) oraz stosowania użyźniacza glebowego UGmax na właściwości prozdrowotne korzeni spichrzowych marchwi poddanych procesowi mrożenia (kostka po uprzednim blanszowaniu wodnym). Przeprowadzone doświadczenia wykazały wysoce istotne znaczenie odmiany w kształtowaniu właściwości prozdrowotnych korzeni spichrzowych marchwi. Największymi właściwościami antyutleniającymi odznaczała się purpurowa odmiana 'Deep Purple', której pojemność antyoksydacyjna wyniosła średnio 5,31 mmol $\mathrm{Fe}^{+2} \bullet \mathrm{kg}^{-1}$ ś.m. Decydująca o właściwościach prozdrowotnych okazała się zawartość antocyjanów $\left(R^{2}=0,83\right)$, kwasu chlorogenowego $\left(R^{2}=0,81\right)$ i związków polifenolowych ogółem $\left(R^{2}=0,71\right)$. Stosowanie preparatu biologicznego UGmax poprawiło jakość marchwi w istotny sposób, zwiększając zawartość karotenoidów ogółem oraz ograniczając straty kwasu askorbinowego podczas przetwarzania. Proces mrożenia negatywnie wpłynął na właściwości przeciwutleniające marchwi niezależnie od odmiany jak i stosowanej agrotechniki, w szczególności w przypadku antyutleniaczy rozpuszczalnych w wodzie takich jak antocyjany i kwas askorbinowy. product and the losses during the processing, the choice of raw material as well as reducing the negative physico-chemical changes is essential. One of the most important factors is the choice of an appropriate cultivar, which decides the basic properties of carrot roots such as colour intensity of root, content of biologically active or structural substances [Czapski et al. 2009; Gajewski et al. 2007; Alasalvar et al. 2005], while the corresponding agro-technique may enhance their content considerably. Besides the common treatments, the use of biological, indirect methods to improve yield quality is recommended. One of them is the application of soil fertility enhancers such as UGmax, which may increase the content of humus and improve nutrient sorption, and, hence, positive influences such as growth and development of plants [Truba et al. 2012; Wojtała-Łozowska, Parylak 2010; Sulewska et al. 2009]. 
As the quality and nutritional value of frozen carrot is a result of the genetic potential of the raw materials as well as of the kind of its preparation, the aim of the research was the achievement of high quality and health-promoting properties of carrot roots that are stable during processing. Furthermore, information about the changes of health properties in multi-factorial system, especially due to the application of biologically agents, is very limited.

\section{MATERIALS AND METHODS}

The present study comprised a 2-year field experiment conducted at the Experimental Station of UTP in Mochelek as a three-factorial split-plot design with three repetitions. The considered experimental factors comprised: carrot cultivars with different colours of the root: purple - 'Deep Purple', yellow - 'Mello Yello' and orange 'Flacoro' and 'Karotan', as well as the application of UGmax (total amount of $1.2 \mathrm{I} \mathrm{ha}^{-1}$ ). Carrots were cultivated under constant mineral nutrition of: $\mathrm{N}-70 \mathrm{~kg} \mathrm{~N} \cdot \mathrm{ha}^{-1}, \mathrm{P}-80 \mathrm{~kg} \cdot \mathrm{ha}^{-1}$ as $\mathrm{P}_{2} \mathrm{O}_{5}$ and $\mathrm{K}-100 \mathrm{~kg} \cdot \mathrm{ha}^{-1}$ as $\mathrm{K}_{2} \mathrm{O}$. Half of the produced carrot roots were cut into cubes $(1 \times 1 \times 1 \mathrm{~cm})$ and subjected to blanching $\left(95^{\circ} \mathrm{C}\right.$ for 3 minutes), then to freezing at temperatures of $22^{\circ} \mathrm{C}$ to $24^{\circ} \mathrm{C}$. Evaluations of health-promoting properties of carrot roots were performed colorimetrically on raw as well as on processed material and comprised the determination of the contents of total carotenoids [PN-90/-75101/12], total polyphenolics [Keutgen, Pawelzik 2007], anthocyanins [Keutgen, Pawelzik 2007], total antioxidant capacity FRAP [Keutgen, Pawelzik 2007] and chlorogenic acid [Griffiths et al. 1992]. Ascorbic acid was determined titrimertrically after the method of Pijanowski. The efficacy of the applied agricultural methods for quality improvement and the suitability of different cultivars (traditional and colourful) for the freezing process as well as the increase of their stability were evaluated by the statistical program Statistica 10 for Windows. Results were evaluated statistically by the application of one-way and multiple ANOVA, where homogeneous groups were built after Tukey test at $p \leq 0.05$.

\section{RESULTS AND DISCUSSION}

The conducted research confirmed a significantly lower content of total carotenoids in carrot roots of the yellow cv. 'Mello Yello' compared with the other cvs, irrespective of the used agro-techniques and processing (Table 1). Similar results were obtained by Platta and Kolenda [2008], Gajewski et al. [2007] and Alasalvar et al. [2005], who determined higher carotenoids content in orange and purple carrot roots than in yellow ones. Cultivar determined also the content of polyphenolics (Table 1). The highest content was detected in cv. 'Deep Purple' with a mean value of $4.16 \mathrm{~g} \cdot \mathrm{kg}^{-1} \mathrm{f}$.m, and the lowest in cv. 'Mello Yello' $\left(0.4 \mathrm{~g} \cdot \mathrm{kg}^{-1}\right.$ f.m.). Similar results were published by Grassman et al. [2007], Gajewski et al. [2007] and Alasalvar et al. [2005]. The mean polyphenol content in carrot roots, mainly as chlorogenic acid, was highest in cv. 'Deep Purple' (2.12 $\mathrm{g} \cdot \mathrm{kg}^{-1}$ f.m.). The other cvs did not differ in their content and their mean value was $0.51 \mathrm{~g} \cdot \mathrm{kg}^{-1}$ f.m. (Table 1). Sun et al. [2009] reported a polyphenol content of purple cvs of $7.7-18.7 \mathrm{~g} \cdot \mathrm{kg}^{-1}$ f.m., of yellow cvs of $0.3 \mathrm{~g} \cdot \mathrm{kg}^{-1}$ f.m. and of orange ones of $0.63-1.15 \mathrm{~g} \cdot \mathrm{kg}^{-1} \mathrm{f}$.m. In addition, in cv. 'Deep Purple' the amount of anthocyanins was $76.3 \mathrm{mg} \cdot \mathrm{kg}^{-1}$ f.m (Table 1) comparable with those reported by Sun et al. [2009], Alasalvar et al. [2005] and Kidoń et al. [2008]. Cultivars differed also in their ascorbic acid contents (Table 1), which was highest in cv. 'Mello Yello' (74.1 $\mathrm{mg} \cdot \mathrm{kg}^{-1} \mathrm{f}$. $\mathrm{m}$ ) and lowest in the orange cv. 'Flacoro' $\left(67.9 \mathrm{mg} \cdot \mathrm{kg}^{-1}\right.$ f.m). These results are opposite to those of Alasalvar et al. [2005]. The results of single antioxidants were also reflected in the total antioxidant capacity FRAP of carrot roots (Table 1), where the cv. 'Deep Purple' reached a 5.7 times higher content compared with other cvs $\left(5.31 \mathrm{mmol} \mathrm{Fe}{ }^{+2} \cdot \mathrm{kg}^{-1}\right.$ f.m.). The results are in line with those of Sun et al. [2009], Gajewski et al. [2007] and Alasalvara et al. [2005].

The application of the soil fertility enhancer UGmax significantly increased the content of total carotenoids in all investigated cvs (Table 1), especially in cvs 'Deep Purple' (31.9\%) and 'Karotan' $(33.5 \%)$. This increase was probably caused by higher availability of minerals, reduction of losses in soil leaching processes, and in consequences with their higher accumulation, and plant quality [Frąckowiak-Pawlak 2009]. No statistical influence of UGmax on the contents of polyphenolics, chlorogenic acid and FRAP value was found (Table 1). In the case of anthocyanins, UGmax significant reduced their concentration by $25.5 \%$. This influence was also found after freezing (drop of $31.5 \%$ ). Observed changes were a result of higher availability of minerals and better growing conditions of carrot roots and lower incidence of suboptimal cultivation conditions, which favoured the synthesis of antioxidants. In fresh carrots of cv. 'Mello Yello', the application of UGmax significantly improved root quality by increasing ascorbic acid content by about $7.5 \%$ (Table 1 ).

The freezing process belongs to the best preservation methods of food, where frozen products remain their nutritional, sensory and health-promoting values to higher extents [Fik et al. 2008]. In the present research, the freezing process did not significantly influence carotenoids content in carrot roots. This indicates their stability during processing combined with a low suceptibility to leaching, whereas UGmax did not stabilize root quality significantly. These findings are inconsistent with the results of Koca and Karadeniz [2008], Kozłowska-Wojciechowska [2007] and Gębczyński [2006], who deteced considerable losses of about $20-40 \%$ of carotenoids during freezing. Furthermore, no significant losses of total polyphenolics as by Koca \& Karadeniz [2008] and Gębczyński [2008] were found. In contrast to these studies, no significant influence of processing on total antioxidant capacity FRAP was detected; however, cv. 'Deep Purple' showed higher amounts compared with other cvs. The situation was different in the case of anthocyanins and vitamin C. Here, considerable losses as a result of the blanching process were found. Observed losses accounted for $52.8 \%$ and $6.1 \%$, respectively. These changes were combined with material grinding, oxygen availability and leaching of substances by water blanching, because these substances are easily soluble in water, especially as glycosidic bonds. High ascorbic acid losses of $40-50 \%$, even up to $100 \%$ as a result of freezing, were also noted by Wronowska and Zadernowski [2012] and Fik et al. [2008]. The highest losses during freezing were determined in cv. 'Mello Yello' (7.4\%) and 'Karotan' (6.1\%), and lowest in cv. 'Deep Purple' and 'Flacoro' (on average $4.7 \%$ ). Application of UGmax reduced the losses by about the half $(49.3 \%)$.

A higher FRAP value was positively associated in the investigated carrot roots with higher content of water-soluble antioxidants such as anthocyanins $\left(R^{2}=0.83^{* *}\right)$, chlorogenic acid $\left(R^{2}=0.81^{* * *}\right)$ and total polyphenolics $\left(R^{2}=0.71^{* * *}\right)$. A correlation between the FRAP value and total carotenoids was not observed. which can be partially explained by the characteristic of antioxidant capacity measurement.

\section{CONCLUSIONS}

The conducted research determined the largest influence of cultivar on health-promoting properties in carrot roots. The highest antioxidative quality was found in the cv. 'Deep Purple'. The application of UGmax played a minor role; however, it caused the 


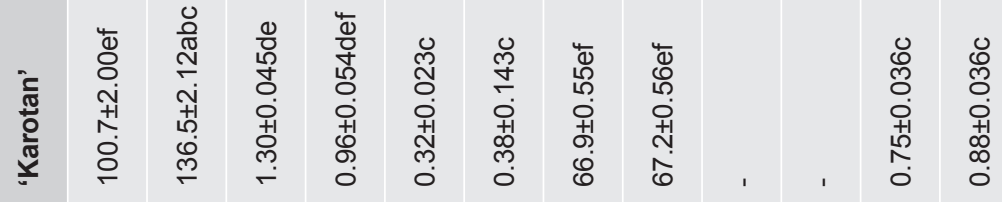

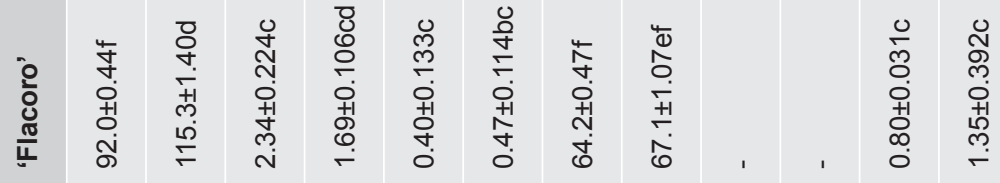

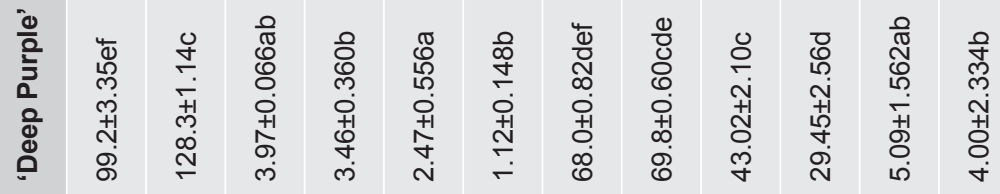

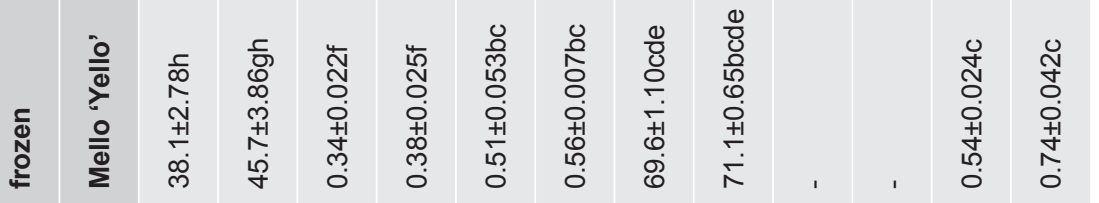

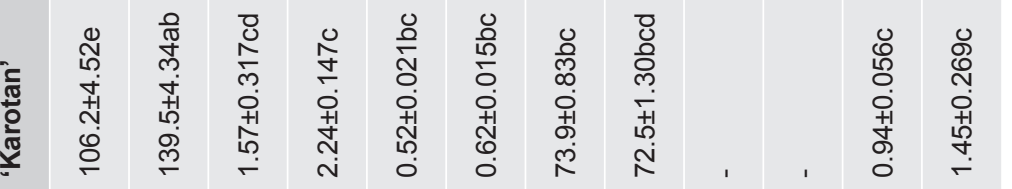

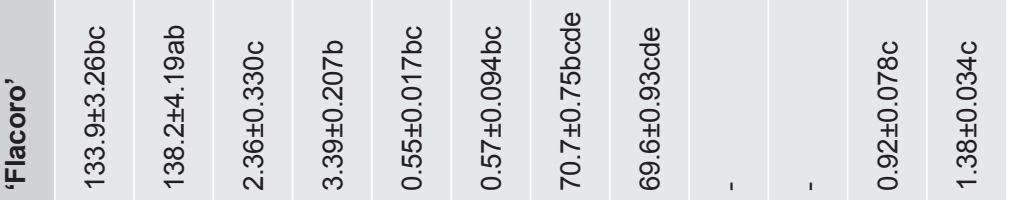

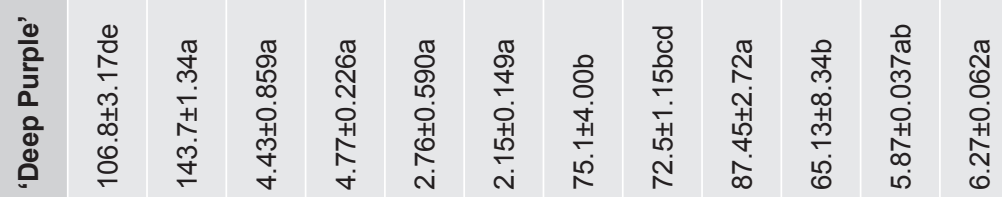

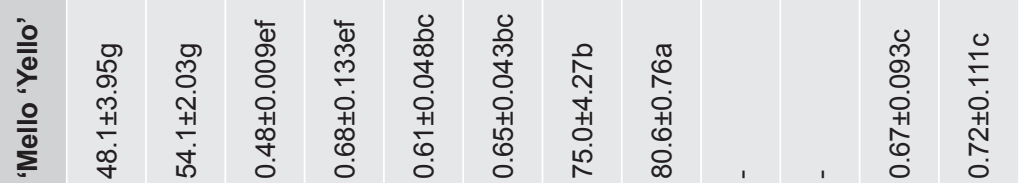

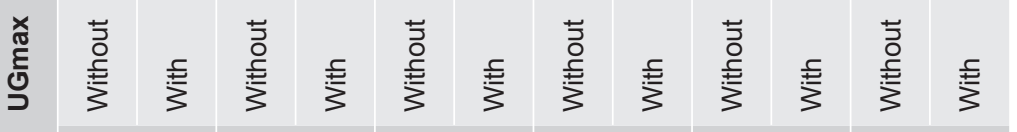


increase in carotenoids content, reduction of ascorbic acid losses during processing and the decrease of anthocyanins. Generally, the negative effects of processing were found only in the case of instable ascorbic acid and water-soluble anthocyanins, which indicates an appropriate freezing process. In summary, it is recommended to apply the biological UGmax for the improvement of antioxidant properties of carrots roots and their stability during processing. For a high health-promoting value of the raw and processed product, the cv. 'Deep Purple' should be cultivated. Publication was carried out with the use of instruments bought in the framework of "Development of State 2 of Regional Centre for Innovativeness" confirmed by the European Found for Regional Development in the framework of the Regional Operation Program of Kuyavian-Pomeranian for 2007-2013.

\section{REFERENCES AND LEGAL ACT}

ALASALVAR C., AL-FARSI M., QUANTICK P.C., SHAHIDI F., WIKTOROWICZ R. 2005. Effect of chill storage and MAP on antioxidant activity, anthocyanins, carotenoids, phenolics and sensory quality of ready-to-eat shredded orange and purple carrots. Food Chem. 89: 69-76.

CZAPSKI J., KIDOŃ M., OLEJNIK A., WITROWA-RAJCHERT D. 2009. Marchew purpurowa jako surowiec dla przetwórstwa owocowo-warzywnego. Przemysł Fermentacyjny i Owocowo-Warzywny 1: 31-33.

FIK M., MACURA R., ZAWIŚLAK A. 2008. Wpływ blanszowania marchwi i gotowania mrożonek na zmiany zawartości karotenoidów i właściwości antyoksydacyjne. Chłodnictwo (XLIII) 6: 66-70.

FRACCKOWIAK-PAWLAK K. 2009. UGmax a plon roślin uprawnych. Pięcioletnie wyniki badań wpływu UGmax Użyźniacza Glebowego na plonowanie roślin. Inż. Ekol. 28: 2-8.

GAJEWSKI M., SZYMCZAK P., ELKNER K., DĄBROWSKA A., KRET A., DANILCENKO H. 2007. Some aspects of nutritive and biological value of carrot cultivars with orange, yellow and purpled-colored roots. Vegetable Crops Res. Bulletin 67: 149-161.

GĘBCZYŃSKI P. 2008. Zmiany zawartości wybranych związków przeciwutleniających w mrożonych warzywach w zależności od obróbki wstępnej, warunków składowania i sposobu przygotowania do spożycia. Wydawnictwo Akademii Rolniczej im. H. Kołłątaja, Kraków.

GRASSMANN J., SCHNITZLER, HABEGGER R.W.H. 2007. Evaluation of different coloured carrot cultivars on antioxidative capacity based on their carotenoid and phenolic contents. International Journal of Food Sciences and Nutrition 58, 8: 603-611.

GRIFFITHS D.W., BAIN H., DALE M.F.B. 1992. Development of rapid colorimetric method for the determination of chlorogenic acid in freeze-dried potato tubers. Journal Science Food Agriculture 58: 41-48.

KEUTGEN A.J., PAWELZIK E. 2007. Modifications of strawberry fruit antioxidant pools and fruit quality under $\mathrm{NaCl}$ stress. Journal Agriculture Food Chemistry 55: 4066-4072.

KIDOŃ M., CZAPSKI J., WITROWA-RAJCHERT D. 2008. Marchew purpurowa i jej przetwory jako źródło związków prozdrowotnych. Bromat. Chem. Toksykol. XLI, 3: 771-776.

KOCA N., KARADENIZ F. 2008. Changes of bioactive compounds and anti-oxidant activity during cold storage of carrots. Intern. J. Food Science \& Technology 43,11: 2019-2025.

LAVELLI V., PAGLIARINI E., AMBROSOLI R., MINATI J.L., ZANONI B. 2006. Physicochemical, microbial, and sensory parameters as indices to evaluate the quality of minimally-processed carrots. Postharvest Biology and Technology 40: 34-40.

NOSECKA B. 2008. Polska marchew dla nas i dla Europy. Owoce Warzywa Kwiaty 20: 9-11.

PLATTA A., KOLENDA H. 2008. Jakość sensoryczna ugotowanej marchwi mrożonej wybranych odmian. Bromat. Chem. Toksykol. XLI, 3: 314-318.

PN-90/A-75101.12. Przetwory owocowe i warzywne. Oznaczanie zawartości sumy karetonoidów i $\beta$-karotenu. PKN, Warszawa 1990.

SULEWSKA H., SZYMAŃSKA G., PECIO A. 2009. Ocena efektów stosowania użyźniacza glebowego UGmax w uprawie kukurydzy na ziarno i kiszonkę. Journal of Research and Applications in Agricultural Engineering 54, 4: 120-125.

SUN T., SIMON P.W., TANUMIHARDJO S.A. 2009. Antioxidant phytochemicals and antioxidant Capacity of biofortified carrots (Daucus carota L.) of various colors. J. Agric. Food Chem. 57: 4142-4147.

TRUBA M., JANKOWSKI K., SOSNOWSKI J. 2012. Reakcja roŚlin na stosowanie preparatów biologicznych. Ochr. Środow. Zasob. Natu. 53: 41-52.

WOJTAŁA-ŁOZOWSKA L., PARYLAK D. 2010. Porażenie pszenicy ozimej przez choroby podsuszkowe w zależności od przedplonu, zastosowania użyźniacza glebowego i materiału siewnego. Prog. Plant Protection 50(4): 2057-2064.

WRONOWSKA B., ZADERNOWSKI R. 2012. Skład chemiczny marchwi białej White Satin F1 świeżej i mrożonej. Bromat. Chem. Toksykol. XLV, 3: 364-369. 